\title{
Clinical and imaging features of children with autoimmune encephalitis and MOG antibodies
}

Andreas Wegener-Panzer, MD, Robert Cleaveland, MD, Eva-Maria Wendel, MD, Matthias Baumann, MD, Annikki Bertolini, MD, Martin Häusler, MD, Ellen Knierim, MD, Edith Reiter-Fink, MD, Markus Breu, MD, Özcan Sönmez, MD, Adela Della Marina, MD, Renate Peters, MD, Christian Lechner, MD, Martin Piepkorn, MD, Claudia Roll, MD, Romana Höftberger, MD, Frank Leypoldt, MD, Markus Reindl, PhD, and Kevin Rostásy, MD

Neurol Neuroimmunol Neuroinflamm 2020;7:e731. doi:10.1212/NXI.0000000000000731

\section{Abstract \\ Objective}

To describe the presentations, radiologic features, and outcomes of children with autoimmune encephalitis associated with myelin oligodendrocyte glycoprotein antibodies (MOG abs).

\section{Methods}

Identification of children fulfilling the diagnostic criteria for possible autoimmune encephalitis (AE) and testing positive for serum MOG abs. Chart review and comprehensive analysis of serum MOG abs using live cell assays and rat brain immunohistochemistry.

\section{Results}

Ten children ( 4 girls, 6 boys) with AE and serum MOG abs were identified. The median age at onset was 8.0 years (range: $4-16$ years). Children presented with a combination of encephalopathy $(10 / 10)$, headache $(7 / 10)$, focal neurologic signs $(7 / 10)$, or seizures $(6 / 10)$. CSF pleocytosis was common (9/10, median 80 white cell count $/ \mu \mathrm{L}$, range: $21-256)$. Imaging showed cortical and deep gray matter involvement in all in addition to juxtacortical signal alterations in $6 / 10$ children. No involvement of other white matter structures or contrast enhancement was noted. MOG abs were detected in all children (median titer 1:640; range: 1: $320-1: 10,540$ ). Nine children had a favorable outcome at discharge (modified Rankin scale of $<$ 2). Five of 10 children had up to 3 additional demyelinating relapses associated with persisting MOG abs. One child had NMDA receptor (NMDAR) abs at initial presentation. A second child had a third demyelinating episode with MOG abs with overlapping NMDAR encephalitis.

\section{Discussion}

AE associated with serum MOG abs represents a distinct form of autoantibody-mediated encephalitis in children. We therefore recommend including MOG abs testing in the workup of children with suspected AE.

\author{
Correspondence \\ Dr. Rostásy \\ k.rostasy@kinderklinik-datteln.de
}




\section{Glossary}

$\mathbf{a b}=$ antibody; $\mathbf{A D E M}=$ acute disseminated encephalomyelitis; $\mathbf{A D S}=$ acquired demyelinating syndrome; $\mathbf{A E}=$ autoimmune encephalitis; $\mathbf{A Q P 4}=$ aquaporin 4; $\mathbf{C B A}=$ cell-based assay; FLAIR = fluid-attenuated inversion recovery; FLAMES = unilateral FLAIR-hyperintense Lesions in Anti-MOG-associated Encephalitis with seizures; HSV = herpes simplex virus; IVIG = IV immunoglobulins; IVMP = IV methylprednisolone; MOG = myelin oligodendrocyte glycoprotein; MOG-SD = MOG spectrum disease; $\mathbf{m R S}=$ modified Rankin scale; NMDAR = NMDA receptor; NMOSD = neuromyelitis optica spectrum disorders; $\mathbf{O N}=$ optic neuritis; TBA $=$ tissue-based screening; $\mathbf{W C C}=$ white cell count.

During the past decade, antibodies (abs) against myelin oligodendrocyte glycoprotein (MOG) have been described in different subgroups of acquired demyelinating syndromes (ADSs) distinct from aquaporin 4 (AQP4) abs-associated syndromes and MS. ${ }^{1,2}$ MOG spectrum diseases (MOG-SDs) manifest primarily in children with isolated or recurrent optic neuritis $(\mathrm{ON})$, isolated or combined with myelitis, or acute disseminated encephalomyelitis (ADEM) ${ }^{3-7}$

The defining features of ADEM are the presence of encephalopathy, polyfocal neurologic signs, and typical MRI findings. ${ }^{8,9}$

Relapsing forms other than MS in children which are nearly always associated with MOG abs include multiphasic ADEM, ADEM followed by optic neuritis (ADEMON), and AQP-4 negative neuromyelitis optica spectrum diseases (NMOSDs). ${ }^{5,10,11}$

More recently, adult studies described patients with autoimmune encephalitis (AE), MOG abs, and MRI features such as cortical involvement of the brain. ${ }^{12-14}$ One study reported 3 adult patients with encephalitis, unilateral cerebral cortical lesions, and epileptic seizures in association with MOG abs. ${ }^{12}$ Recently, Budhram et al. ${ }^{15}$ reported an adult patient with MOG abs, encephalitis, seizures, and unilateral cortical involvement terming the acronym FLAMES (unilateral fluidattenuated inversion recovery [FLAIR]-hyperintense Lesions in Anti-MOG-associated Encephalitis with seizures) after a detailed literature review of similar cases.

Reports of children with clinical and radiologic presentations in the context of MOG abs are limited. In a recent study of 18 patients with ab-mediated encephalitis, 2 children with unilateral cortical involvement on MRI and MOG abs were identified. ${ }^{16}$

The aim of this study was to describe the clinical features, treatment response, outcome, and the neuroradiologic features of 10 children presenting with encephalitis associated with MOG abs.

\section{Methods}

\section{Patients}

We identified 10 pediatric patients who (1) fulfilled the criteria of possible $\mathrm{AE},{ }^{17}$ (2) were tested positive for serum MOG abs, (3) had brain MRI findings primarily restricted to the cortical and deep gray matter structures, and (4) showed no involvement of deep white or periventricular white matter areas, cerebellum, brainstem, or spinal cord at initial presentation, thus failing the classification criteria for ADEM.

Nine children were followed prospectively, and one child was identified retrospectively (Pat 1 , table). Three children were primarily seen at the Children's Hospital Datteln (A.W.-P., A.B., and K.R.) where testing of MOG abs is routinely performed in patients with ADS and encephalitis. One child was initially included in the GENERATE study—a study focusing on patients presenting with encephalitis in which testing for MOG abs is also included. In the remaining 6 children, MOG $a b$ testing was performed as part of a locally established protocol and discovered by chance with the exception of patient 7 who had previously a MOG ab-positive ON. All 7 children were referred to the attention of the senior author (K.R.) because of the unusual combination of clinical findings, MOG ab positivity, and cortical involvement as seen on MRI. All children had virologic, bacterial, and immunologic workup according to the local guidelines. Clinical features, laboratory, and neuroimaging findings performed in the first 48 hours of clinical presentation and outcome of all children were reviewed. Severity at onset and outcome at the last clinical evaluation was measured with the modified Rankin scale (mRS). ${ }^{18}$

\section{Serological studies}

In 9 children, serum MOG ab testing was performed using live cell-based assays (CBAs), and end point titrations were performed as previously described. ${ }^{19}$ Median titers in patients with and without relapses were compared using MannWhitney $U$ tests (GraphPad Prism 8). Serum MOG abs were tested in one child with a fixed CBA (Euroimmun, Lübeck, Germany), and this titer was not included in the statistics. CSF was available in 7 children and tested with live CBAs. ${ }^{19}$ Tissue-based screening (TBA) for neuronal surface abs in serum and CSF using rat brain was performed in $7 / 10$ children. Nine of 10 children ( 7 serum and CSF, 2 serum only) were examined by commercially available biochips (Euroimmun) for the following antigens: NMDA receptor (NMDAR) consisting of NR1 subunits only, GAD65, LGI1, CASPR2, AMPAR subunit 2, $\gamma$-aminobutyric acid-B receptors, and glycine receptors. ${ }^{20}$

\section{MRI}

MRI scans were evaluated by 3 neuroradiologists (A.W.-P., R.C., and M.B.). All reviewers were blinded for the patients' 
Table Demographic, clinical data, laboratory findings, and MRI features of children with MOG-E

\begin{tabular}{|c|c|c|c|c|c|c|c|c|c|c|c|c|c|c|c|c|c|c|c|c|c|c|c|c|}
\hline & \multirow[b]{2}{*}{$\begin{array}{l}\text { Age } \\
\text { (y) }\end{array}$} & \multirow[b]{2}{*}{ Sex } & \multirow[b]{2}{*}{ Prodrome } & \multicolumn{3}{|c|}{ Clinical presentation } & \multicolumn{2}{|c|}{ Laboratory } & \multirow{2}{*}{$\begin{array}{l}\text { Findings } \\
\\
\text { CSF MOG } \\
\text { ab titer 1: }\end{array}$} & \multirow[b]{2}{*}{$\begin{array}{l}\text { Positive } \\
\text { CSF-OCB }\end{array}$} & \multirow[b]{2}{*}{ Awake EEG } & \multicolumn{7}{|c|}{ MRI findings } & \multirow[b]{2}{*}{ Treatment } & \multirow{2}{*}{$\begin{array}{l}\text { Outcome } \\
\mathrm{mRS} / \text { last } \\
\mathrm{FU}(\mathrm{mo})\end{array}$} & \multirow[b]{2}{*}{$\begin{array}{l}\text { MOG ab } \\
\text { FU-titer }\end{array}$} & \multirow[b]{2}{*}{ Final Dx } & \multirow[b]{2}{*}{ Relapses } & \multirow[b]{2}{*}{ Remarks } \\
\hline at. & & & & $\begin{array}{l}\text { Fever > } \\
38.5^{\circ} \mathrm{C}\end{array}$ & Symptoms & $\mathrm{mRS}$ & $\begin{array}{l}\text { CSF } \\
\text { cells/ } \\
\mu \mathrm{L}\end{array}$ & $\begin{array}{l}\text { Serum } \\
\text { MOG-ab } \\
\text { titer 1: }\end{array}$ & & & & $\begin{array}{l}\text { Cortical } \\
\text { gray } \\
\text { matter }\end{array}$ & $\begin{array}{l}\text { Juxta } \\
\text { cortical } \\
\text { WM }\end{array}$ & DGM & $\begin{array}{l}\text { Insular } \\
\text { cortex }\end{array}$ & $\begin{array}{l}\text { Lesion } \\
\text { pattern }\end{array}$ & $\begin{array}{l}\text { WM, BS, } \\
\text { cerebral, } \\
\text { myelon }\end{array}$ & $\begin{array}{l}\mathrm{CM} \\
\text { enhancement }\end{array}$ & & & & & & \\
\hline & 14 & $\mathrm{~F}$ & Headache & Yes & $\begin{array}{l}\text { Mental status } \\
\text { changes, } \\
\text { somnolence, } \\
\text { focal seizures, } \\
\text { left } \\
\text { hemiparesis }\end{array}$ & 4 & 256 & 640 & ND & No & $\begin{array}{l}\text { Marked } \\
\text { slowing right } \\
\text { hemisphere }\end{array}$ & Yes & No & No & Yes & Unilateral & No & No & PB, aciclovir & $1 / 48$ & $\begin{array}{l}2 \text { mo: } 1: 100 \\
\text { (1. relapse, } \\
\text { Euroimmun); } \\
3 \text { mo: 1:100 } \\
\text { (2. relapse, } \\
\text { Euroimmun); } \\
40 \text { mo: } 1: 320 \\
\text { (3. relapse); } \\
46 \text { mo: } 1: 640\end{array}$ & $\begin{array}{l}\text { MOG-E/ } \\
\text { relapsing } \\
\text { MOGSD }\end{array}$ & 3 & $\begin{array}{l}\text { 2. relapse } \\
\text { MOG/ } \\
\text { NMDAR-E } \\
\text { (10/2015) } \\
\text { SCIG/ } \\
\text { monthly } \\
\text { after 3. } \\
\text { relapse } \\
\text { (11/2018) }\end{array}$ \\
\hline & 12 & M & $\begin{array}{l}\text { Headache, } \\
\text { GE }\end{array}$ & Yes & $\begin{array}{l}\text { Mental status } \\
\text { changes, } \\
\text { somnolence, } \\
\text { ataxia }\end{array}$ & 5 & 21 & 320 & Neg & No & $\begin{array}{l}\text { Generalized } \\
\text { slowing }\end{array}$ & Yes & Yes & Yes & Yes & Bilateral & No & No & $\begin{array}{l}\text { IVMP, IVIG, } \\
\text { prednisolone- } \\
\text { taper } 8 \mathrm{w}\end{array}$ & $1 / 6$ & $3 \mathrm{mo}: 1: 40$ & MOG-E & 0 & \\
\hline & 16 & $\mathrm{~m}$ & Headache & Yes & $\begin{array}{l}\text { Severe } \\
\text { headache, } \\
\text { somnolence, } \\
\text { dysarthric } \\
\text { speech, } \\
\text { unable to } \\
\text { walk securely }\end{array}$ & 4 & 44 & 640 & Neg & No & $\begin{array}{l}\text { Slowing right } \\
\text { parietal lobe }\end{array}$ & Yes & No & No & No & Bilateral & No & No & $\begin{array}{l}\text { IVMP, } \\
\text { prednisolone- } \\
\text { taper } 8 \mathrm{w}\end{array}$ & $1 / 12$ & 12 mo: 1:80 & MOG-E & 0 & $\begin{array}{l}\text { Bilateral } \\
\text { hippocampus } \\
\text { involvement }\end{array}$ \\
\hline & 10 & M & Headache & Yes & $\begin{array}{l}\text { Seizures, } \\
\text { dysesthesias of } \\
\text { the left leg, } \\
\text { audiovisual } \\
\text { hallucinations, } \\
\text { sleep disorders }\end{array}$ & 4 & 96 & 320 & $\begin{array}{l}\text { Traumatic } \\
\text { LP }\end{array}$ & $\begin{array}{l}\text { Traumatic } \\
\text { LP }\end{array}$ & $\begin{array}{l}\text { Slowing right } \\
\text { temporal }\end{array}$ & Yes & Yes & No & Yes & Unilateral & No & Yes & $\begin{array}{l}\text { IVMP, IVIG, } \\
\text { RTX } \times 2 \text {, } \\
\text { prednisolone- } \\
\text { taper } 8 \mathrm{w}\end{array}$ & $1 / 6$ & $4 \mathrm{mo}: 1: 160$ & MOG-E & 0 & $\begin{array}{l}\text { Concomittant } \\
\text { NMDAR abs } \\
\text { in } \\
\text { CSF } 1 . \\
\text { episode }\end{array}$ \\
\hline & 5 & M & $\begin{array}{l}\text { URTI, } \\
\text { febrile } \\
\text { seizure }\end{array}$ & Yes & $\begin{array}{l}\text { Encephalopathy } \\
\text { with } \\
\text { somnolence, } \\
\text { ataxia }\end{array}$ & 4 & 4 & 1280 & Neg & No & $\begin{array}{l}\text { Generalized } \\
\text { slowing, } \\
\text { bilateral SWs }\end{array}$ & Yes & Yes & Yes & Yes & Bilateral & No & No & IVIG, IVMP & $1 / 42$ & $\begin{array}{l}12 \text { mo: 1:160; } \\
30 \text { mo: } 1: \\
2560 \\
\text { (1. relapse), } \\
33 \text { mo:1: } \\
\text { 10,240 } \\
\text { (2. relapse) }\end{array}$ & $\begin{array}{l}\text { MOG-E/ } \\
\text { relapsing } \\
\text { MOGSD }\end{array}$ & 2 & RTX 7x \\
\hline & 6 & M & Headache & No & $\begin{array}{l}\text { Severe } \\
\text { headache, } \\
\text { somnolence, } \\
\text { focal seizures }\end{array}$ & 4 & 136 & 640 & ND & ND & $\begin{array}{l}\text { Severe } \\
\text { generalized } \\
\text { slowing }\end{array}$ & Yes & Yes & No & No & Bilateral & No & No & $\begin{array}{l}\text { IVMP, IVIG, } \\
\text { MMF, } \\
\text { levetiracetam }\end{array}$ & $1 / 24$ & $\begin{array}{l}6 \mathrm{mo:}: 1: 640 \\
\text { (1. relapse) } \\
17 \text { mo: } 1: 160\end{array}$ & $\begin{array}{l}\text { MOG-E/ } \\
\text { relapsing } \\
\text { MOGSD }\end{array}$ & 1 & \\
\hline & 7 & $\mathrm{~F}$ & URTI & Yes & $\begin{array}{l}\text { Somnolence, } \\
\text { left } \\
\text { heimiparesis, } \\
\text { focal seizures }\end{array}$ & 3 & 32 & 1280 & Neg & No & $\begin{array}{l}\text { Slowing right } \\
\text { temporal lobe }\end{array}$ & Yes & No & No & Yes & Unilateral & No & No & IVMP & $1 / 48$ & $3 \mathrm{mo:} 1: 1,280$ & $\begin{array}{l}\text { MOG-E/ } \\
\text { relapsing } \\
\text { MOGSD }\end{array}$ & 1 & $\begin{array}{l}\text { 1. episode } \\
\text { with ON; } \\
3 \text { mo prior: } \\
\text { MOG abs: } \\
\text { 1: } 1,280\end{array}$ \\
\hline & 6 & $\mathrm{~F}$ & GE & Yes & $\begin{array}{l}\text { Somnolence, } \\
\text { ataxia }\end{array}$ & 4 & 91 & 2540 & 32 & No & Normal & Yes & Yes & No & No & Unilateral & No & Not done & IVMP & $1 / 11$ & $\begin{array}{l}4 \text { mo: } 1: 640 \\
\text { (1. relapse) }\end{array}$ & $\begin{array}{l}\text { MOG-E/ } \\
\text { relapsing } \\
\text { MOGSD }\end{array}$ & 1 & \\
\hline
\end{tabular}


clinical data. Minimum requirements of the brain MRI sequences for inclusion were axial T2, axial FLAIR, sagittal $\mathrm{T} 2$, diffusion-weighted, and contrast-enhanced axial T1 images, which were not administered in one child. In 2 children, the MRI was performed on scanners with a field strength of $1.0 \mathrm{~T}$, in 6 with $1.5 \mathrm{~T}$ and in 2 with $3.0 \mathrm{~T}$. In 8 patients, spinal cord MRI was performed.

Distribution of lesions was assessed regarding the involvement of certain regions such as cortical gray matter, juxtacortical, deep and periventricular white matter, corpus callosum, thalamus, basal ganglia, brainstem, and cerebellum. ${ }^{21}$ Furthermore, the following features were recorded: (1) areas of restricted diffusion (high signal on diffusion-weighted imaging and low signal on apparent diffusion coefficient) and (2) gadolinium-enhancing lesions. Spinal MRI was analyzed for the presence of transverse myelitis (figure 1).

\section{Standard protocol approvals, registrations, and patient consents}

This study was approved by the Ethics Committee of the Witten/Herdecke University, Germany (BIOMARKER-Study number AN4059). All caregivers gave informed consent.

One patient was included in the GENERATE-study (study number EK 26-16) approved by the Ethics Committee of the Medical University RWTH Aachen, Germany.

\section{Data availability}

All relevant data generated or analyzed are included in this published article. Further anonymized data will be shared upon request from any qualified investigator.

\section{Results}

We identified 10 children fulfilling the criteria of possible $\mathrm{AE}^{17}$ in whom as part of the workup serum MOG abs were found. The cohort consisted of 4 female and 6 male patients with a median age at onset of 8.0 years (range: $4-16$ years). Five of 10 children had signs of a mild preceding infection affecting the upper respiratory or gastrointestinal tract (table and figure 2).

All children presented with signs of encephalopathy associated with fever (temperature $\left.>38.5^{\circ} \mathrm{C}\right)(8 / 10)$, severe headache $(7 /$ $10)$, febrile or afebrile seizures $(6 / 10)$, and neurologic symptoms, including ataxia, hemiparesis, or dysarthria $(7 / 10)$. The modified Rankin scale (mRS) in the initial phase was $3(\mathrm{n}=1)$, $4(\mathrm{n}=7)$, and $5(\mathrm{n}=2)$. Four children were referred temporarily to the intensive care unit. CSF pleocytosis ( $>4$ white cell count $/ \mu \mathrm{L}$ ) was detected in $9 / 10$ children with a median of 80 cells/ $\mu \mathrm{L}$ (range: $21-256$ ). CSF protein was elevated in 3 children (range: $56-120 \mathrm{mg} / \mathrm{dL}$ ).

EEG was performed in 9 children, revealing generalized or focal slowing in $7 / 9$ children in the first 48 hours of the 
Figure 1 Clinical details and brain MRI from patient 1 with autoimmune encephalitis and serum myelin oligodendrocyte glycoprotein (MOG) antibodies

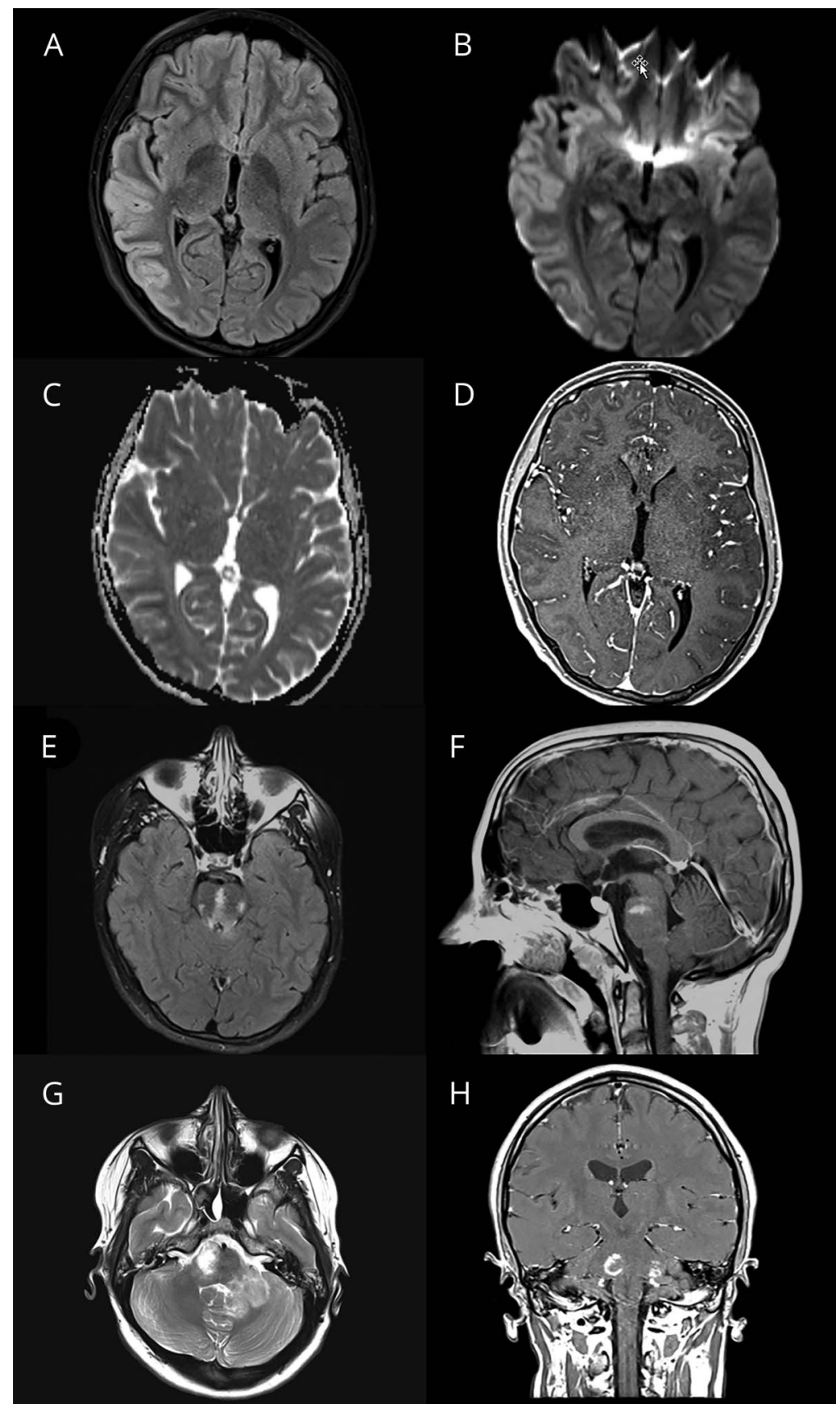

Cerebral MRI of a 14-year-old girl (Pat 1) who presented to the emergency department with severe headache, mental status changes, and seizures. Fluid-attenuated inversion recovery image shows pronounced signal alterations and effacement of the cortical gray matter, particularly in the right temporal-parietal lobe (A). In addition, increased signal intensity was noted on signal diffusion weighted-imaging, but no corresponding hypointense apparent diffusion coefficient areas reflecting vasogenic edema rather than cytotoxic injury (B and C). Contrast enhancement of the right temporal-parietal lobe was not seen (D). Four months later, she developed a third episode with sudden onset of memory problems, aggression, sleeping problems, and social withdrawal. Autoantibody studies in CSF and serum revealed NMDA receptor antibodies (abs) in addition to serum MOG abs. MRI of the brain showed a new and large T2 signal alteration in the pons with contrast enhancement ( $E$ and $F$ ). She was treated with steroids and rituximab. A fourth episode occurred 2 years and 10 months after the initial onset with dizziness and ataxia. Cerebral MRI showed a new patchy T2-hyperintense signal in the right pons and in the left cerebellar white matter ( $G$ and $H)$. All lesions resolved completely without residuals. Since the third relapse, she was treated with subcutaneous immunoglobulins. presentation. Epileptic discharges were recorded only in one child in the acute phase. EEG recording in all children normalized after steroid treatment.

Search for different pathogens in stool, throat swab, serum, and CSF was undertaken in all children including Herpes simplex virus (HSV)-PCR, which was negative in all.

In addition to antibiotic and antiviral therapy, 8/10 children were treated with high-dose IV methylprednisolone (IVMP) for 3 to 5 days with a daily dose of $20 \mathrm{mg} / \mathrm{kg}$ (maximum $1 \mathrm{~g} / \mathrm{d}$ ). One child received IV immunoglobulins (IVIG; $2 \mathrm{~g} / \mathrm{kg}$ / bodyweight) given for 5 days.

At 4 weeks, 9 children had a favorable neurologic outcome (mRS 1 ), and one child had a residual left-sided hemiparesis (mRS 2) needing further rehabilitation. This child only received the diagnosis of MOG encephalitis 4 years later and had not been treated with IVMP nor IVIG at the time (supplementary file 1, Pat 1, links.lww.com/NXI/A245). 
Figure 2 Clinical details and brain MRI from patient 2 with autoimmune encephalitis and serum myelin oligodendrocyte glycoprotein antibodies

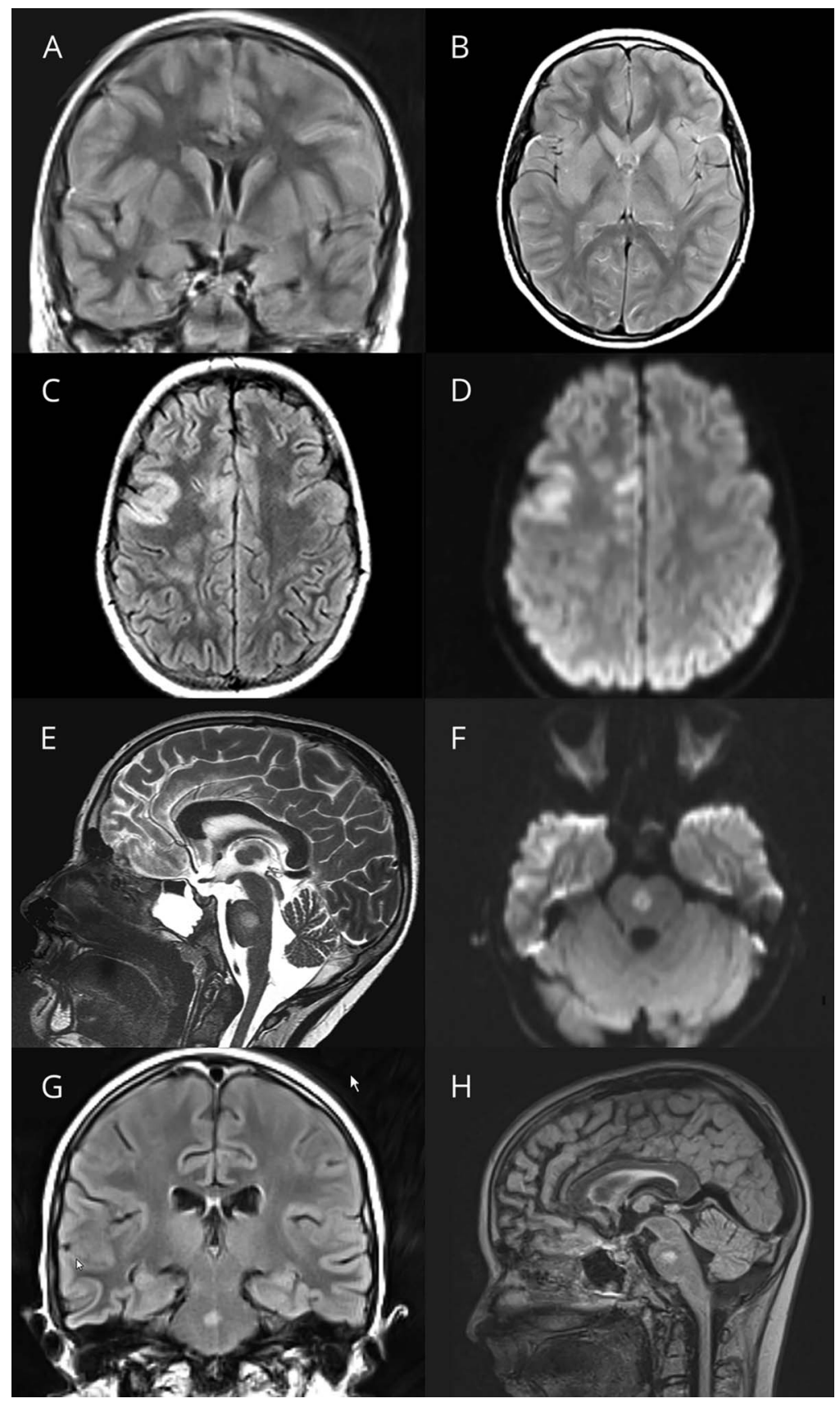

First cerebral MRI of a 12-year-old boy (Pat 2) with encephalopathy, fever, and ataxia reveals generalized edema of the cerebral cortex and the basal ganglia including the caudate nucleus, putamen, and globus pallidum. The initial examination was superimposed with strong movement artifacts, despite which the cortical edema can still be noted in the shown fluid-attenuated inversion recovery images ( $A$ and $B$ ). The second MRI of the brain performed 7 days later after treatment with high-dose cortisone and immunoglobulins still showed cortical involvement of the right fronto-temporal lobe (C). In the diffusion-weighted images, "T2-shinethrough" (D) but no apparent diffusion coefficient (ADC) signal depression was found. In addition, a single new central pontine lesion was noted in the sagittal T2 images with increased signal intensity in diffusion-weighted imaging and ADC signal depression this time as a sign of cytotoxic injury ( $E$ and $F$ ) but still without contrast enhancement. In the third MRI of the brain performed 18 days after admission, the central pontine lesion was still present ( $G$ and $H$ ) associated with ADC depression (not shown).

The follow-up interval was between 6 and 48 months in all children with an average follow-up of 20 months. Five children had a monophasic disease course, and 5 children relapsed. Time to 1 relapse was between 2 and 30 months. Two children developed one relapse, one child had 2 relapses, and one child had 3 relapses, and all were diagnosed with relapsing MOG-SD. In one child (Pat 7), MOG encephalitis developed after an initial episode of unilateral ON 3 months earlier.

Two children with relapsing episodes were started on disease-modifying therapies. One child receives monthly subcutaneous immunoglobulins $(0.85 \mathrm{~g} / \mathrm{kg} / \mathrm{mo})$ (table, Pat 1). The other child was started on rituximab with a dose of $375 \mathrm{mg} / \mathrm{m}^{2}$ body surface area and 7 consecutive applications (table, Pat 5).

Serum MOG abs were detected in the acute phase in all children with a median titer of 1:640 (range: 1:320-1: $10,240)$. In the 5 children with a monophasic course, all serum MOG ab titers declined to below 1:160 during the median follow-up interval of 11 months (range: 6-24). In 2 children with one further relapsing event, serum MOG abs dropped to 
Figure 3 Clinical details and brain MRI from patient 3 with autoimmune encephalitis and serum myelin oligodendrocyte glycoprotein (MOG) antibodies

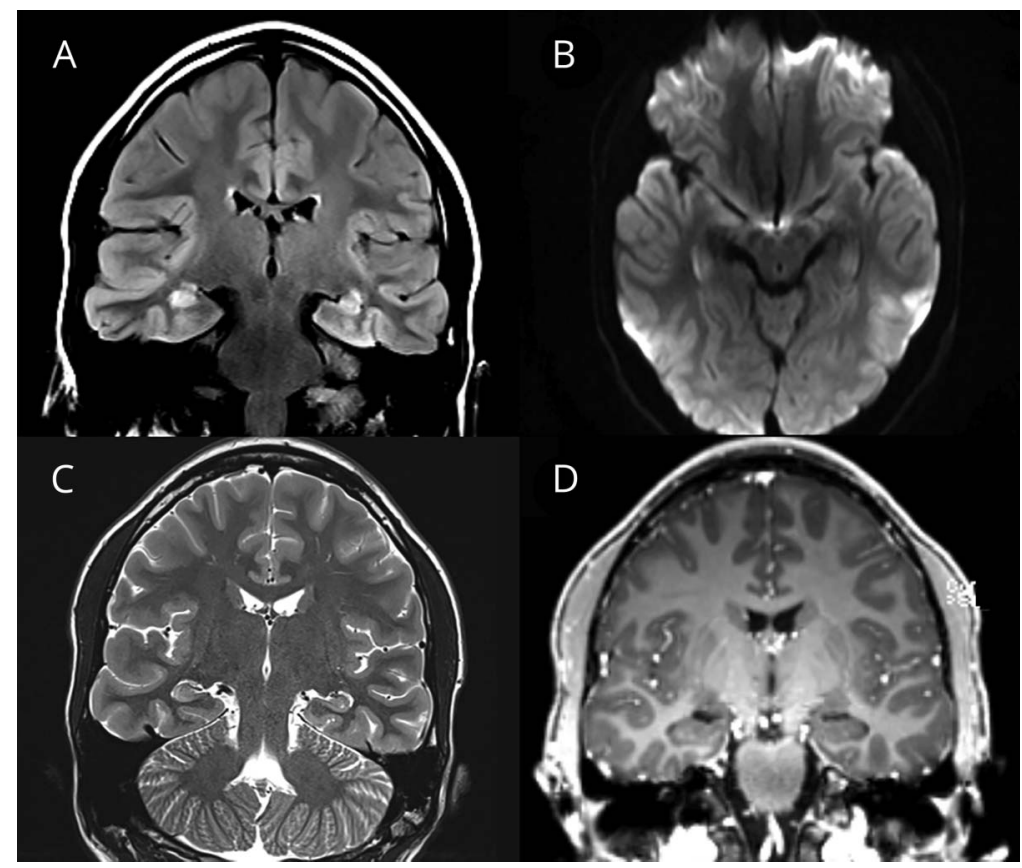

MRI of the brain of a previously healthy 16 -year-old boy (Pat 3) who presented to the emergency department with a 6-day history of severe right-sided headache shows bilateral signal alterations in both hippocampi, particularly in the coronal fluid-attenuated inversion recovery sequences more pronounced on the right than left side (A). In the T2-weighted images, the alterations are less pronounced (C). Diffusion restriction or contrast medium enhancement was not noted in this patient ( $B$ and $D$ ). Follow-up MRI of the brain 3 months later did not reveal any abnormalities (not shown). undetectable levels $(<1: 40)$ after 6 and 10 months, respectively. In the other 3 children with relapsing events, MOG $\mathrm{ab}$ titers remained in the range of 1:320 and 1:640 over a follow-up period of 33 months (range: 9-48 months). At the time of the last relapse or last follow-up, median MOG serum titers were higher in patients with relapses (median 640, 95\% CI 320-10,240) than in patients without relapses (median 60, $95 \%$ CI 20-160, $p=0.016$ ). In 7 children, MOG abs were also tested in CSF (table) with no apparent intrathecal synthesis. Serum and/or CSF samples of 3/7 children reacted strongly with rat epitopes of MOG, showing a myelin staining pattern, which was not observed in any of the other $4 / 7$ children tested using rat brain immunohistochemistry. Of note, one child also had NMDAR abs in serum and CSF (titer 1:10 in CBA and confirmed in TBA). Interestingly, although this child presented primarily with somnolence, increasing headache, and seizures, hallucinations were also described in the acute phase (table, Pat 4).

NMDAR abs were found in one other child in CSF and serum who developed symptoms suggestive of NMDAR encephalitis in addition to MOG encephalitis (Pat 1, see below). In both children, subsequent testing for serum NMDAR abs 12 (Pat 1) and 4 months later was negative (Pat 4).

\section{MRI findings in children with encephalitis and MOG abs at disease onset}

MRI was performed in 6 different hospitals. All children had involvement of the cerebral cortex and to a lesser extent of deep gray matter structures, including the thalami (3/10). In addition to cortical involvement, a small rim of the adjacent juxtacortical white matter was affected in 6/10 children. In none of the children additional lesions in the corpus callosum, deep, or periventricular white matter were detected. Involvement of the optic nerves, brainstem, cerebellum, or spinal cord was also not noted. Bilateral limbic involvement of both hippocampi was present in one patient (table, Pat 3, figure 3).

Diffusion restrictions were not found, and pathologic contrast enhancement was absent in all patients, except for a single case with presumed hemorrhagic and unilateral encephalitis (table, Pat 4, figure 4D) in whom vascular leakage resulted in contrast medium accumulation with no lesion-specific pattern. This child had a single lesion affecting the left temporal cortical and juxtacortical region.

Distribution of lesions was unilateral in 4 children and bilateral in 6 children. The anatomical localization of the cortical changes in the initial MRI of the brain was mostly parietal (8/ $10)$, less frequently frontal $(7 / 10)$, temporal $(5 / 10)$, and occipital (3/10). The insular cortex was affected in 6 children.

In the first available MRI study, several radiologic features were noted in all children: (1) involvement of cortical and deep gray matter structures often associated with juxtacortical signal changes, (2) absent diffusion restriction, (3) no involvement of the optic nerves or other white matter structures such as deep white and periventricular matter, spinal cord, and (4) no lesional contrast enhancement. 
Figure 4 Clinical details and brain MRI from patient 4 with autoimmune encephalitis and serum myelin oligodendrocyte glycoprotein antibodies

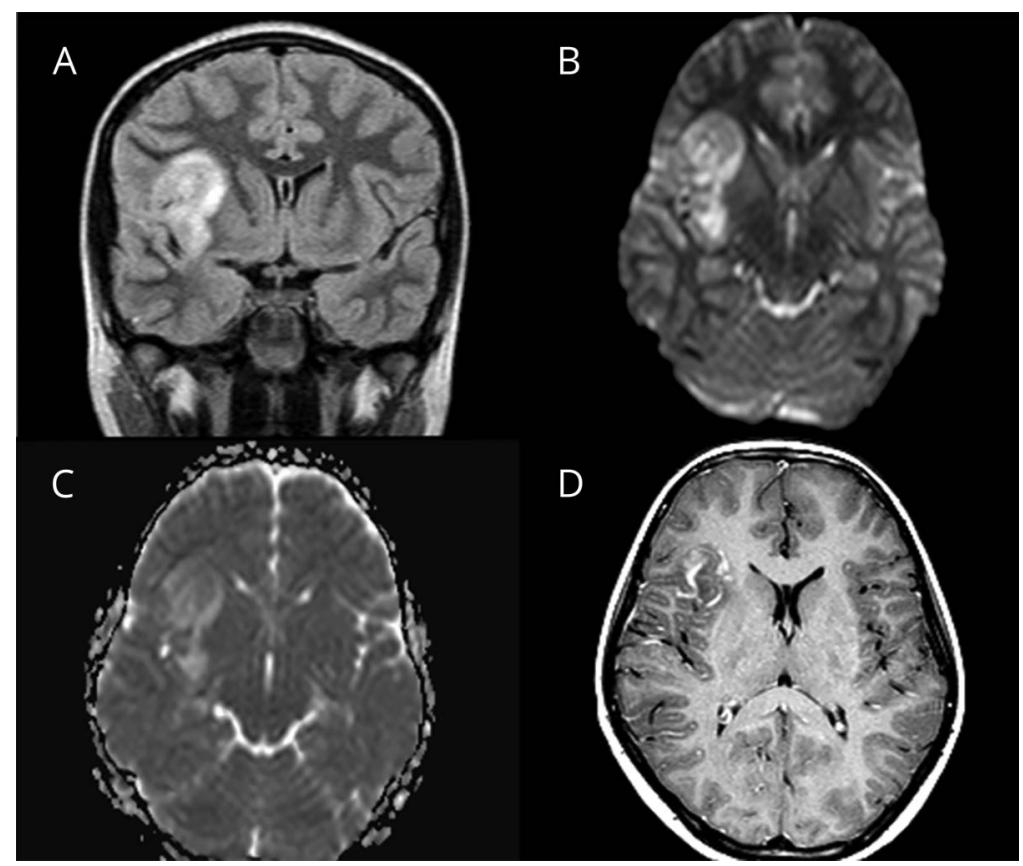

Brain MRI of a 10-year-old boy (Pat 4) with focal seizures, encephalopathy, and fever revealed a large hyperintense lesion of the right insular cortex and the adjacent juxtacortical white matter ( $A$, fluid-attenuated inversion recovery). In the diffusion-weighted images, there is "T2-shinethrough" but no apparent diffusion coefficient signal depression and therefore no diffusion restriction (B and $C$ ). This was the only patient in whom after administration of contrast agent, a streaky, garland-like contrast enhancement in the area of the insular cortex and the juxtacortical white matter on the right was noted (D). We assume that vascular leakage resulted in contrast medium accumulation with no lesion-specific pattern. In this patient, no other areas of the brain were affected.

\section{Case presentation of 3 children with MOG encephalitis}

In the supplemental material, we describe the clinical presentations and further course of 3 patients (see supplementary file 1, links.lww.com/NXI/A245, Pat 1-3, table).

\section{Discussion}

Here, we describe the clinical characteristics, neuroimaging features, and outcome of children presenting with $\mathrm{AE}$ associated with MOG abs, which were distinct from ADEM associated with MOG abs.

All children had a brief prodromal period associated often with severe headache, followed by impairment of consciousness associated with other neurologic symptoms and seizures. All children fulfilled the criteria for possible $\mathrm{AE}$ as proposed by Graus et al. ${ }^{17}$

Children presenting with a presumed encephalitis require immediate treatment to improve neurologic outcome. The differential diagnosis entails pathogen-driven diseases and autoimmune-mediated diseases. In particular, ab-mediated forms of encephalitis have been shown in several studies to be important causes. ${ }^{17,22}$

On clinical grounds and standard laboratory testing, the different entities cannot be separated with a high degree of certainty. MRI plays an important role in the first assessment of patients presenting with clinical signs of encephalitis. Our analysis of the imaging studies of children with MOG encephalitis shows that these children have a radiologic pattern that is distinct from pathogen-induced encephalitis, other forms of ab-mediated AE or ADEM. All children in our sample showed involvement of cortical region with absent diffusion restriction and contrast enhancement. In addition to optic nerves, white matter structures such as deep white were not affected initially, which is in contrast to children with ADEM and MOG abs. Imaging in MOG-positive ADEM is characterized by hazy, large lesions confined to subcortical and deep white areas in addition to areas including the spinal cord. Here, cortical areas can be affected too but not exclusively, as shown previously. ${ }^{9,10}$

MRI findings in HSV encephalitis are mainly restricted to the temporal lobes affecting cortical and white matter areas and are associated with features indicating substantial structural damage such as an increased signal intensity on diffusion-weighted imaging and contrast-medium enhancement. MRI in children with NMDAR encephalitis is often unremarkable, with one-third of patients showing only unspecific MRI changes and very rarely cortical enhancement. $^{23,24}$

Our study further shows that MOG encephalitis in children can (1) occur as a monophasic disease, (2) can continue as a relapsing disease in half of all children with different demyelinating syndromes, and (3) present with features of NMDAR encephalitis at the same time (Pat 1, 4) (table). 
In one study, 2 children with encephalitis, unilateral cortical involvement on MRI, and MOG abs were reported, confirming the presence of MOG encephalitis in children. ${ }^{16}$ Budhram et al. reviewed the literature of patients with serum MOG abs, encephalitis, and seizures. They found that MRI in these patients often reveals a unilateral cortical involvement and coined the acronym FLAMES (unilateral FLAIRhyperintense Lesions in Anti-MOG-associated Encephalitis with seizures). ${ }^{15}$ Two further single cases were recently published, describing children with symptoms suggestive of encephalitis associated with MOG abs but with MRI features more reminiscent of ADEM underscoring the need for precise terminology and diagnostic standards for children with MOG-SD. ${ }^{25,26}$ Recently, Armangue et al. showed that the spectrum of MOG-SD is wider than previously reported including children with encephalitis. ${ }^{27}$ In their large cohort of children with ADS and encephalitis, they found that 22/296 children with definite or possible AE harbored MOG abs.

We could not delineate serologic or CSF findings specific to MOG encephalitis in comparison to other MOG-SD. Reaction with rat epitopes has been described as associated with NMOSD phenotype, yet we did observe this in $3 / 7$ of our patients, ${ }^{28}$ supporting the notion of including TBA using rat brain sections in the workup of pediatric AE. Intrathecal synthesis of MOG abs has been speculated earlier to be associated with ADEM in contrast to NMOSD phenotypes, yet this was not observed in any of the 7 patients with testing available in CSF and serum. ${ }^{29}$ Another interesting observation in our case series is that 2 children with MOG encephalitis either had NMDAR abs in serum and CSF at initial presentation or presented with a severe clinical manifestation of NMDAR encephalitis 4 months later. In adults, the occurrence of overlapping demyelinating syndromes associated with MOG or AQP4 abs and subsequent episodes of encephalitis with NMDAR abs has been described. ${ }^{30}$ The simultaneous presence of both abs was also reported recently in a large study of children with NMDAR encephalitis, which found that more than $10 \%$ of affected children also harbored MOG abs. ${ }^{16}$ There was no difference in the CSF cell count of children with MOG encephalitis in our cases series compared with children with ADEM or NMDAR encephalitis. ${ }^{7}$

Encephalitis in children remains a severe disease despite recent advances. Timely diagnosis is of utmost importance, and delay may thus contribute to significant long-term sequelae. The differential diagnosis is broad, ranging from viral, bacterial, fungal, and parasitic infections to possible and definite cases of $\mathrm{AE}$ and other forms of immune-mediated diseases such as ADEM. Metagenomic next-generation sequencing is emerging as a new approach for the diagnosis of infectious causes which can be identified by using a single assay, most likely increasing the detection rate of pathogeninduced encephalitis. ${ }^{31}$ In addition, novel neuronal cellsurface and synaptic autoantibodies have been identified in recent years expanding the spectrum of definite causes of $\mathrm{AE}^{32-34}$
MOG abs directed against epitopes of MOG of the myelin sheath of oligodendrocytes appears to be another culprit in the events leading to the manifestation of an $\mathrm{AE}$. In contrast to the variable clinical manifestation in NMDAR encephalitis, children with MOG encephalitis, as far as we observed, present commonly with fever, headache, somnolence, seizures, and a characteristic imaging pattern with good response to steroids.

Limitations that need to be addressed as follows: (1) small sample size and a lack of comparison with other children who fulfill the diagnostic criteria for AE but do not have MOG abs, (2) not all children were followed prospectively, and (3) children with a monophasic disease course had shorter followup period compared with the one with a relapsing disease course. In addition, (4) not in all children, autoantibody testing for neuronal antigens was performed in the CSF, thus leading to an underestimate of other autoantibodies involved. Finally, (5) the outcome was tested only with mRS, thereby not accurately assessing cognitive function in this form of encephalitis.

AE with serum MOG abs represents a further form of autoantibody-mediated encephalitis in children and MOG encephalitis should therefore be considered in the differential diagnosis, particularly in the presence of cortical involvement on MRI. Diagnostic workup of pediatric patients with suspected AE should include TBA using rat brain immunohistochemistry and live cell MOG abs assays.

\section{Author contributions}

A. Wegener-Panzer and K. Rostásy designed and directed the study. K. Rostásy wrote the first draft of the manuscript. R. Höftberger, F. Leypoldt, and M. Reindl conducted the serologic testing of patient samples and revised the manuscript. All authors contributed and analyzed the data and read and revised the manuscript.

\section{Acknowledgment}

The authors thank the children and their families who agreed to take part in this study.

\section{Study funding}

This study is supported by grants numbers 14158 and 15918 (K. Rostasy) and 16919 (R. Höftberger) from the Jubilaeumsfonds of the Austrian National Bank and research grant "BIG WIG MS" from the Austrian Federal Ministry of Science, Research and Economy (Markus Reindl).

\section{Disclosure}

A. Wegener-Panzer, R. Cleaveland, E.-M. Wendel, M. Baumann, A. Bertolini, M. Häusler, E. Knierim, E. Reiter-Fink, M. Breu, Ö. Sönmez, A. Della Marina, R. Peters, C. Lechner, M. Piepkorn, C. Roll, and R. Höftberger report no disclosures related to the present work. F. Leypoldt reports speaker honoraria from Grifols, Teva, Biogen, Bayer, Roche, Novartis, Fresenius, travel funding from Merck, Grifols and Bayer and 
serving on advisory boards for Roche, Biogen and Alexion. K. Rostásy received speaker's honoraria from Novartis and served on the advisory board of the PARADIGM study. M. Reindl receives payments for ab assays (MOG, AQP4, and other autoantibodies) and for MOG and AQP4 ab validation experiments organized by Euroimmun (Lübeck, Germany). Go to Neurology.org/NN for full disclosures.

\section{Publication history}

Received by Neurology: Neuroimmunology \& Neuroinflammation February 17, 2020. Accepted in final form March 25, 2020.

\section{References}

1. Ketelslegers IA, Van Pelt DE, Bryde S, et al. Anti-MOG antibodies plead against MS diagnosis in an acquired demyelinating syndromes cohort. Mult Scler 2015;12: 1513-2030.

2. Hacohen Y, Absoud M, Deiva K, et al. Myelin oligodendrocyte glycoprotein antibodies are associated with a non-MS course in children. Neurol Neuroimmunol Neuroinflamm 2015;2:e81. doi: 10.1212/NXI.0000000000000081.

3. Pröbstel AK, Dornmair K, Bittner R, et al. Antibodies to MOG are transient in childhood acute disseminated encephalomyelitis. Neurology 2011;77:580-588.

4. Rostasy K, Mader S, Hennes EM, et al. Persisting myelin oligodendrocyte glycoprotein antibodies in aquaporin-4 antibody negative pediatric neuromyelitis optica. Mult Scler 2013;69:1052-1059.

5. Lechner C, Baumann M, Hennes EM, et al. Antibodies to MOG and AQP4 in children with neuromyelitis optica and limited forms of the disease. J Neurol Neurosurg Psychiatry 2016;87:897-905.

6. Waters P, Fadda G, Woodhall M, et al. Serial anti-myelin oligodendrocyte glycoprotein antibody analyses and outcomes in children with demyelinating syndromes. JAMA Neurol 2019;77:e192940.

7. Hennes EM, Baumann M, Schanda K, et al. Prognostic relevance of MOG antibodies in children with an acquired demyelinating syndrome. Neurology 2017;89: 900-908.

8. Krupp LB, Tardieu M, Amato MP, et al. International Pediatric Multiple Sclerosis Study Group criteria for pediatric multiple sclerosis and immune-mediated central nervous system demyelinating disorders: revisions to the 2007 definitions. Mult Scler 2013;10:1261-1267.

9. Baumann M, Sahin K, Lechner C, et al. Clinical and neuroradiological differences of paediatric acute disseminating encephalomyelitis with and without antibodies to the myelin oligodendrocyte glycoprotein. J Neurol Neurosurg Psychiatry 2015;86: 265-272.

10. Baumann M, Hennes EM, Schanda K, et al. Children with multiphasic disseminated encephalomyelitis and antibodies to the myelin oligodendrocyte glycoprotein (MOG): extending the spectrum of MOG antibody positive diseases. Mult Scler 2016;22:1821-1829.

11. Huppke P, Rostasy K, Karenfort M, et al. Acute disseminated encephalomyelitis followed by recurrent or monophasic optic neuritis in pediatric patients. Mult Scler 2013;19:941-946.

12. Ogawa R, Nakashima I, Takahashi T, et al. MOG antibody-positive, benign, unilateral, cerebral cortical encephalitis with epilepsy. Neurol Neuroimmunol Neuroinflamm 2017;4:e322. doi: 10.1212/NXI.0000000000000322.

13. Fujimori J, Takai Y, Nakashima I, et al. Bilateral frontal cortex encephalitis and paraparesis in a patient with anti-MOG antibodies. J Neurol Neurosurg Psychiatry 2017;88:534-536.
14. Hamid SHM, Whittam D, Saviour M, et al. Seizures and encephalitis in myelin oligodendrocyte glycoprotein IgG disease vs aquaporin $4 \mathrm{IgG}$ disease. JAMA Neurol 2018;74:65-71.

15. Budhram A, Mirian A, Le C, et al. Unilateral cortical FLAIR-hyperintense lesions in anti-MOG-associated encephalitis with seizures (FLAMES): characterization of a distinct clinic-radiographic syndrome. J Neurol 2019;266:2481-2487.

16. Zhang J, Ji T, Qian Chen Q, et al. Pediatric autoimmune encephalitis: case series from two Chinese Tertiary Pediatric Neurology Centers. Front Neurol 2019;10:906.

17. Graus F, Titulaer MJ, Balu R, et al. A clinical approach to diagnosis of autoimmune encephalitis. Lancet Neurol 2016;15:391-404.

18. Patel N, Rao VA, Heilman-Espinoza ER, et al. Simple and reliable determination of the modified Rankin scale score in neurosurgical and neurological patients. Neurosurgery 2012;71:971-975.

19. Mader S, Gredler V, Schanda K, et al. Complement activating antibodies to myelin oligodendrocyte glycoprotein in neuromyelitis optica and related disorders. J Neuroinflammation $2011 ; 8: 184$.

20. Dalmau J, Lancaster E, Martinez-Hernandez E, Rosenfeld MR, Balice-Gordon R Clinical experience and laboratory investigations in patients with anti-NMDAR encephalitis. Lancet Neurol 2011;10:63-74.

21. Verhey LH, Branson HM, Laughlin S, et al. Development of a standardized MRI scoring tool for CNS demyelinationin children. AJNR Am J Neuroradiol 2013;34: 1271-1277.

22. Venkatesan A, Tunkel AR, Bloch KC, et al; International Encephalitis Consortium. Case definitions, diagnostic algorithms, and priorities in encephalitis: consensus statement of the International Encephalitis. Clin Infect Dis 2013;8:1114-1128.

23. Armangue T, Titulaer MJ, Málaga I, et al. Pediatric anti-N-methyl-D-aspartate receptor encephalitis-clinical analysis and novel findings in a series of 20 patients. J Pediatr 2013;162:850-856.

24. Wright S, Hacohen Y, Jacobson L, et al. N-methyl-D-aspartate receptor antibodymediated neurological disease: results of a UK-based surveillance study in children Arch Dis Child 2015;100:521-526.

25. Zhong X, Chang Y, Tan S. Relapsing optic neuritis and meningoencephalitis in a child: case report of delayed diagnosis of MOG-IgG syndrome. BMC Neurol 2019;11:94

26. Tani H, Ishikawa N, Kobayashi $\mathrm{Y}$, et al. Anti-MOG antibody encephalitis mimicking neurological deterioration in a case of Rett syndrome with MECP2 mutation. Brain Dev 2018;10:943-946.

27. Armangue T, Olivé-Cirera G, Martinez-Hernandez E, et al. Associations of paediatric demyelinating and encephalitic syndromes with myelin oligodendrocyte glycoprotein antibodies: a multicentre observational study. Lancet Neurol 2020; 19:234-246.

28. Sepúlveda M, Armangue T, Martinez-Hernandez E, et al. Clinical spectrum associated with MOG autoimmunity in adults: significance of sharing rodent MOG epitopes. J Neurol 2016;263:1349-1360.

29. Körtvélyessy P, Breu M, Pawlitzki M, et al. ADEM-like presentation, anti-MOG antibodies, and MS pathology: TWO case reports. Neurol Neuroimmunol Neuroinflamm 2017;4:e335. doi: 10.1212/NXI.0000000000000335.

30. Titulaer MJ, Höftberger R, Isuka $\mathrm{T}$, et al. Overlapping demyelinating syndromes and anti-N-methyl-D-aspartate receptor encephalitis. Ann Neurol 2014;75:411-428.

31. Wilson MR, Sample HA, Zorn KC, et al. Clinical metagenomic sequencing for diagnosis of meningitis and encephalitis. N Engl J Med 2019;380:2327-2340.

32. Petit-Pedrol M, Armangue T, Peng X, et al. Encephalitis with refractory seizures, status epilepticus, and antibodies to the GABAA receptor: a case series, characterisation of the antigen, and analysis of the effects of antibodies. Lancet Neurol 2014;13: 276-286.

33. Lancaster E, Martinez-Hernandez E, Titulaer MJ, et al. Antibodies to metabotropic glutamate receptor 5 in the Ophelia syndrome. Neurology 2011;77:1698-1701.

34. Nosadini M, Toldoa I, Tasciniaet B, et al. LGI1 and CASPR2 autoimmunity in children: systematic literature review and report of a young girl with Morvan syndrome. J Neuroimmunol 2019;335:577008. 


\title{
Neurology ${ }^{\oplus}$ \\ Neuroimmunology \& Neuroinflammation
}

\author{
Clinical and imaging features of children with autoimmune encephalitis and MOG \\ antibodies \\ Andreas Wegener-Panzer, Robert Cleaveland, Eva-Maria Wendel, et al. \\ Neurol Neuroimmunol Neuroinflamm 2020;7; \\ DOI 10.1212/NXI.0000000000000731
}

This information is current as of May 1, 2020

Neurol Neuroimmunol Neuroinflamm is an official journal of the American Academy of Neurology.

Published since April 2014, it is an open-access, online-only, continuous publication journal. Copyright

Copyright $\odot 2020$ The Author(s). Published by Wolters Kluwer Health, Inc. on behalf of the American

Academy of Neurology.. All rights reserved. Online ISSN: 2332-7812.

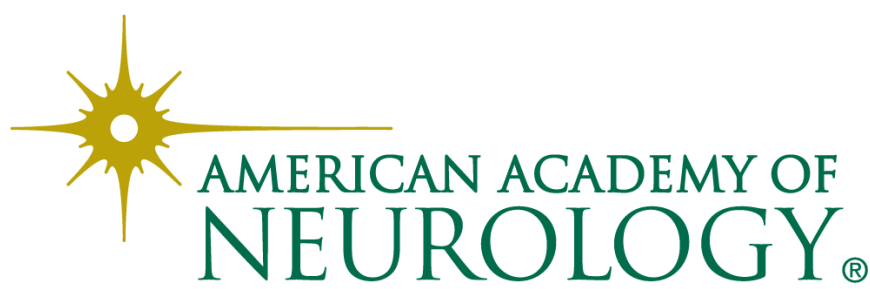




\section{Updated Information \& Services}

References

Citations

Subspecialty Collections

Permissions \& Licensing

Reprints including high resolution figures, can be found at: http://nn.neurology.org/content/7/4/e731.full.html

This article cites 34 articles, 8 of which you can access for free at: http://nn.neurology.org/content/7/4/e731.full.html\#\#ref-list-1

This article has been cited by 6 HighWire-hosted articles: http://nn.neurology.org/content/7/4/e731.full.html\#\#otherarticles

This article, along with others on similar topics, appears in the following collection(s):

Acute disseminated encephalomyelitis

http://nn.neurology.org//cgi/collection/acute_disseminated_encephalo myelitis

All Pediatric

http://nn.neurology.org//cgi/collection/all_pediatric

Autoimmune diseases

http://nn.neurology.org//cgi/collection/autoimmune_diseases

MRI

http://nn.neurology.org//cgi/collection/mri

Information about reproducing this article in parts (figures,tables) or in its entirety can be found online at:

http://nn.neurology.org/misc/about.xhtml\#permissions

Information about ordering reprints can be found online: http://nn.neurology.org/misc/addir.xhtml\#reprintsus

Neurol Neuroimmunol Neuroinflamm is an official journal of the American Academy of Neurology.

Published since April 2014, it is an open-access, online-only, continuous publication journal. Copyright

Copyright $\odot 2020$ The Author(s). Published by Wolters Kluwer Health, Inc. on behalf of the American Academy of Neurology.. All rights reserved. Online ISSN: 2332-7812.

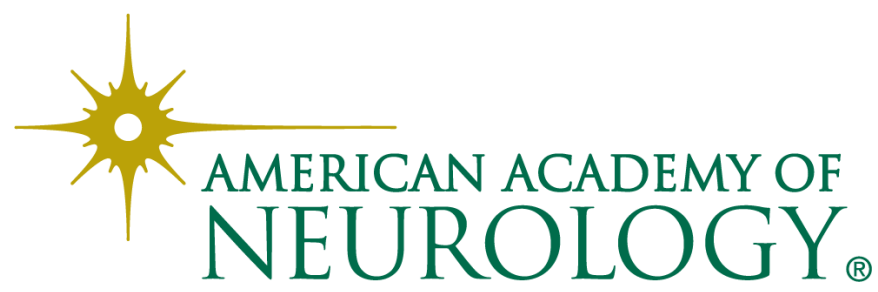

